\title{
Understanding nSARS-CoV-2 and Pneumonia Co-infection-Review
}

\author{
Raghavendra Rao.M. V' ${ }^{*}$, Mubasheer Alii ${ }^{2}$, Yogendra Kumar Verma ${ }^{3}$, Mahendra Kumar Verma ${ }^{4}$, Dilip Mathai ${ }^{5}$, \\ Tiara Calvo Leon ${ }^{6}$, Chennamchetty Vijay Kumar ${ }^{7}$, Gil C Apacible ${ }^{8}$, Aruna Kummari ${ }^{9}$ \\ ${ }^{1}$ Department of Medicine, Apollo Institute of Medical Sciences and Research, Jubilee Hills, Hyderabad, India \\ ${ }^{2}$ Consultant, MD Internal Medicine, Apollo Hospitals and Apollo Tele Health Services, Associate Professor \\ Department of General Medicine, Shadan Medical College, India \\ ${ }^{3}$ Assistant Professor, Microbiology, Mandsaur University, Mandsaur, Madhya Pradesh, India \\ ${ }^{4}$ Assistant Professor, American University School of Medicine Aruba, Caribbean islands \\ ${ }^{5}$ Professor, Department of Medicine, \& Dean, Apollo Institute of Medical Sciences and Research, Hyderabad, India \\ ${ }^{6}$ Associate Professor, American University School of Medicine Aruba, Caribbean islands \\ ${ }^{7}$ Associate Professor, Department of Pulmonary Medicine, Apollo Institute of Medical Science and Research, \\ Hyderabad, TS, India \\ ${ }^{8}$ Associate Professor, Anatomical \& Developmental Sciences, Neuroscience, Behavioral Science, and Preventive \\ Medicine Epidemiology, American University School of Medicine Aruba, Caribbean islands \\ ${ }^{9}$ Associate Professor, Department of Respiratory Medicine, ESIC Medical College, Sanathnagar Hyderabad, TS, India
}

*Address for Correspondence: Prof. M. V. Raghavendra Rao, Scientist-Emeritus and Director, Central research laboratory, Apollo Institute of Medical sciences and research, Jubilee Hills, Hyderabad, TS, India

E-mail: reachdrmvrrao@gmail.com

Received: 26 Jun 2021/ Revised: 23 Aug 2021/ Accepted: 03 Oct 2021

\begin{abstract}
The world is living on the brink.COVID-19, an exciting, outstanding pandemic co-infected with bacterial pneumonia, which demands crucial Public Health Intervention. Covid pandemic created significant economic, social, and medical ambiguity. COVID-19 pneumonia is a severe illness and life-threatening. Coronavirus damages the cells and tissue that line the air sacs of the lungs. The walls of the sacs are thickened and obstruct the diffusion of gases. Bacterial pneumonia is the sixth leading cause of death in the US. Pneumonia can be caused by multifarious bacteria, viruses and fungi in the air we breathe. Bacterial pneumonia disturbs a part, or lobe, of a lung. This condition is described as lobar pneumonia
\end{abstract}

Key-words: Pneumococcal pneumonia, Klebsiella pneumonia, Hemophilus influenza, Staphylococcal pneumonia, Atypical pneumonia, legionella pneumonia, Mycoplasma pneumoniae, Chlamydia psittaci, G-CSF (Granulocyte colony-stimulating factor), TNF (Tumor necrosis factor).

\section{INTRODUCTION}

Prolonged mechanical ventilation may expose COVID-19 patients to a higher risk of super pulmonary infection. $A$. baumannii and $S$. aureus co-infection of the respiratory tract in COVID-19 patients admitted to ICU were observed. The nasal microbiome of COVID 19 patients possesses Acinetobacter, and Pseudomonas ${ }^{[1]}$.

\section{How to cite this article}

Raghavendra RMV, Alii M, Verma YK, Verma MK, Mathai $D$, et al. Understanding nSARS-CoV-2 and Pneumonia Co-infection-Review. SSR Inst. Int. J. Life Sci., 2021; 7(6): 2913-2920.

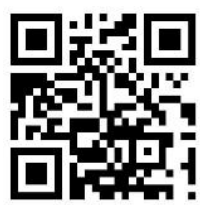

pathogens that cause health care and ventilatorassociated pneumonia, including non-fermenting and fermenting gram-negative bacteria (most notably, $A$. baumannii, $P$. aeruginosa, $K$. pneumoniae, $E$. coli, $S$. maltophila) and $S$. aureus ${ }^{[2,3]}$.

Respiratory distress syndrome is complicated by cardiopulmonary and organ failure. Study that sought etiologic agents of infection largely identified nosocomial Postmortem cultures of tissues are susceptible to microbial contamination. Bacterial co-pathogens are commonly identified in viral respiratory tract infections. Bacterial co-infection in patients with severe influenza has been reported with greater severity of illness ${ }^{[4]}$. 
History- Edwin Klebs observed bacteria in the airways of pneumonia patients. The Greek word pneumo meaning is "lung". The symptoms were described by Hippocrates. $S$. pneumoniae and $K$. pneumoniae, was executed by Ehsan et al. ${ }^{[4]}$ and Nicholas et al. ${ }^{[5]}$. Langford et al. ${ }^{[6]}$ demonstrated pneumonia as an opportunistic bacteria present in the lung. Sir William Osler, described pneumonia as the "captain of the men of death" in 1918, pneumonia had overtaken tuberculosis as one of the leading causes of death.

Pneumonia- Inflammation of lung parenchyma with the accumulation of exudates inflammatory cells and fibrin within the alveolar spaces or alveolar septa. It is characterized by consolidation of the affected part of the lung ${ }^{[7]}$. Respiratory diseases are caused by several infectious agents including Streptococcal pneumonia, $S$. pyogenes, K. pneumonia, H. influenzae, L. pneumophila, M. pneumonia, Coxiella burnetii, and C. psittaci. These microbes enter the lungs and cause primary cases of pneumonia ${ }^{[8,9]}$.

Lower respiratory tract microbes- Amniotic fluid filling fetal lungs prenatally was considered sterile. Detectable microbial communities in multiple body sites have been identified in newborns ${ }^{[10]}$. This premature microbiome has been shown to change design and diversity and mature functionally during the first two to three years of life. Bacterial lung infections are usually categorized as acute or chronic depending upon the rate at which they evolve, but more likely related to the quality they resolve after antibiotic therapy ${ }^{[11]}$. This approach applies to chronic obstructive pulmonary disease (COPD), where routine culturing is not recommended. Bacterial infections periodically appear in patients with prolonged hospitalization, and P. aeruginosa, Klebsiella sp., and $S$. aureus were common pathogens ${ }^{[12]}$. Bacterial copathogens are frequently diagnosed in viral respiratory infections and are important causes of morbidity and mortality. Bacterial coinfections occur in less than $5 \%$ of patients who are hospitalized with COVID-19 and are usually caused by S. aureus, S. pneumoniae, and $H$. Influenzae ${ }^{[13,14]}$. Nosocomial infections are common among patients with prolonged hospitalization for COVID-19, and P. aeruginosa, Klebsiella sp. most commonly cause hospital-acquired pneumonia, and $S$. aureus ${ }^{[15]}$.
Klebsiella pneumonia- $K$. pneumonia is a rare disease with high mortality. The cardinal hvKp virulence genes $r m p A, r m p A 2$, iroBCDN, iucABCD, and peg-344, which have been recognized as molecular markers for the identification of hvKp that carry a high risk for disseminated and fatal infections ${ }^{[16,17]}$.

Streptococcus pneumonia- S. pneumoniae is the first cause of community-acquired pneumonia (CAP) $S$. pneumoniae, K. pneumoniae and $H$. influenza were the most common bacterial co-infections. Bacterial coinfections were dominant in all COVID-19 patients; $S$. pneumoniae was the most common, followed by $K$. pneumoniae and $H$. Influenzae ${ }^{[18]}$. Bacteria are the most common cause of CAP Invasive Pneumococcal Disease/ COVID-19 confections do not support current recommendations for any of the available pneumococcal vaccines during the COVID-19 pandemic Senior citizens, who had received a 13 -valent pneumococcal conjugate vaccine (PCV13) have a lower incidence of COVID-19 deaths ${ }^{[19-21]}$.

Mechanism- After entry into the lungs, bacteria may invade the spaces between cells and between alveoli, where the macrophages and neutrophils inactivate the bacteria ${ }^{[22]}$. The neutrophils release cytokines and activate the immune system. Finally produce fever, chills, and fatigue similar to bacterial pneumonia [23]. Consolidation on chest $\mathrm{X}$-rays appears as a result of neutrophils, bacteria, and fluid from surrounding blood vessels ${ }^{[24]}$.

\section{Clinical Situation- Co-infections in CAP and hospital-} acquired pneumonia (HAP)- Lower respiratory tract infections are major causes of morbidity and mortality and are frequently caused by co-infecting pathogens. Identification of the causative agent and encouragement for vaccination promotes infection ${ }^{[25]}$. MRSA can be initiated if patients have necrotizing pneumonia, acute respiratory distress. Antimicrobial resistance is increasing because of the overuse and misuse of antibiotics [26]. COVID-19 pandemic is associated with the higher use of antibiotics which in turn lead to antibiotic resistance

\section{Diagnosis of Lower respiratory tract Bacterial infection} Diagnosis of Covid-19 and bacterial confection- The use of diagnostics became an integral part of modern medicine and involves molecular biology and cutting edge bioengineering as well. Stem cells can remain alive 
in human corpses at least 17 days after death, researchers say ${ }^{[27,28]}$. Gene therapy is viable, available and reliable.

Mucus- The microbiological examination is a practical way for diagnosis, especially sputum culture, However, taking sputum or blood samples from SARS-CoV-2infected patients may pose a significant risk to biological sample collectors and laboratory technicians as the SARS-CoV-2 does not only spread through respiratory droplets and direct contact but also virus-laden aerosols RT-PCR as a primary diagnostic procedure for detecting SARS-CoV-2 ${ }^{[29,30]}$. Mucus is the oil in the engine. Without mucous the engine seizes. The immune system sends white blood cells in the nose to fight for infection. They contain a greenish enzyme that sheds the substance yellow or green:
i. White- Viral infection
ii. Rust red-Pneumococcal
iii. Full red-TB
iv. Bright red-Pulmonary embolism
v. Dark red currant Jelly with blood and mucus- Klebsiella

\section{RT-PCR as a Frontline Diagnostic Method for COVID-19}

Diagnosis- For the diagnosis of COVID-19 and bacterial coinfection of this disease, standardized testing of coinfection is still unavailable. Serological based diagnosis can detect different serum antibodies like IgG, IgM, and IgA in an infected patient.PCR based diagnostic procedures are reliable, not cost-effective tests, rapid, and sensitive with accuracy ${ }^{[1,32]}$. Predominantly identified co-pathogens of SARS-CoV-2 are bacteria such as S. pneumoniae, S. aureus, $K$. pneumoniae, $H$. influenzae, $M$. pneumoniae, A. baumannii, $L$. pneumophila and $C$. pneumoniae followed by viruses including influenza, coronavirus, rhinovirus/enterovirus, parainfluenza, metapneumovirus, influenza B virus, and human immunodeficiency virus ${ }^{[33,34] \text {. }}$

Recent advances- The gene Xisco gene was recently described as a biomarker for PCR based detection of $S$. pneumonia due to low cost and relatively short testing time. EIA serological assays are the most common method of $M$. pneumoniae detection is used in the patient ${ }^{[35]}$.

Breakthrough the treatment- There are currently only a few treatment options available for multidrug-resistant bacteria and the need to develop new antimicrobial therapies to treat co-infections ${ }^{[36]}$. An early study of antibiotic therapy in critically ill patients with CAP showed a significant reduction in mortality when macrolide was used as part of the treatment [37]. Macrolide therapy has additional benefits such as antiinflammatory effects and immunomodulatory effects. Combination therapy of beta-lactam and a macrolide is used in hospitalized and severely ill patients with CAP ${ }^{\text {[38] }}$.

1- Macrolide should be given before the initiation of beta-lactam therapy.

2- Antibiotic therapy should start as soon as possible after the confirmation of CAP.

3- Fluoroquinolone should be carefully considered to be given to patients in areas with endemic tuberculosis. Areas with endemic Tuberculosis prefer macrolides such as clarithromycin/azithromycin over quinolone/doxycycline as initial empiric therapy in patients with CAP.

4- Once the results of the microbiological testing become available, we can then tailor the appropriate treatment to the findings.

The most promising adjunctive treaty-mentoring appears to be corticosteroids; which in multiple RCTs have shown a significant reduction of morbidity, but not mortality for patients with non-complicated CAP ${ }^{[39,40]}$. There has been a bit of a debate about hyperglycemia, the side effects of the corticosteroid therapy, and the harm that did not outweigh the benefits ${ }^{[41-43]}$. Antibiotics for acute exacerbation in patients with chronic pulmonary disease are recommended in two scenarios: firsts to treat an infection associated with an acute exacerbation of COPD and second for prophylaxis. The initial choice should be amoxicillin or amoxicillin-clavulanate, where betalactamase production by the $\mathrm{H}$. Influenzae is prevalent or the use of fluoroquinolone. Other medications to consider are cephalosporins cefuroxime or cefpodoxime; macrolide; piperacillin-tazobactam, cefepime, or ciprofloxacin for pseudomonas or other more-resistant organisms ${ }^{[44,45]}$. Also, there is antibiotic therapy for COPD patients to reduce exacerbation like inhaled corticosteroids, anti-muscarinic agents (long-action), and Phosphodiesterase 4 inhibitors ${ }^{[46,49]}$. 
Title 1: Treatment of choice for typical and atypical Pneumonia

\begin{tabular}{|c|c|c|}
\hline $\begin{array}{l}\text { Typical and } \\
\text { Atypical } \\
\text { pneumonia }\end{array}$ & Causative Organisms & Treatment of choice - antimicrobials \\
\hline \multirow{3}{*}{$\begin{array}{c}\text { Typical } \\
\text { pneumonia }\end{array}$} & H. influenzae & $\begin{array}{l}\text { Intravenous third-generation cephalosporin until antibiotic } \\
\text { sensitivities becomes available of intramuscular ceftriaxone when } \\
\text { IV administration is not available. }\end{array}$ \\
\hline & S. aureus & $\begin{array}{l}\text { Combination therapy with penicillinase-resistant penicillin or } \\
\text { cephalosporin (in case the organism is methicillin-sensitive } S \text {. } \\
\text { aureus [MSSA]) and clindamycin or fluoroquinolone. }\end{array}$ \\
\hline & K. pneumonia & $\begin{array}{l}\text { Third-generation cephalosporins, carbapenems, aminoglycosides, } \\
\text { and quinolones. }\end{array}$ \\
\hline \multirow{4}{*}{$\begin{array}{l}\text { Atypical } \\
\text { pneumonias }\end{array}$} & L. pneumophila & $\begin{array}{l}\text { The treatment should have high intracellular concentrations like } \\
\text { macrolide, quinolones, ketolides, tetracyclines, and rifampins. }\end{array}$ \\
\hline & M. pneumonia & The drugs of choice are either azithromycin or clindamycin. \\
\hline & C. pneumoniae & Tetracyclines and macrolide are the drugs of choice. \\
\hline & C. psittaci & $\begin{array}{l}\text { Tetracycline or doxycycline is the drug of choice. Azithromycin } \\
\text { should be considered as the second line of defence. }\end{array}$ \\
\hline
\end{tabular}

Haemophilus influenza: Intravenous third-generation cephalosporin until antibiotic sensitivities becomes available of intramuscular ceftriaxone $\mathrm{S}$. aureus: combination therapy with penicillinase-resistant penicillin or cephalosporin (and clindamycin a fluoroquinolone ${ }^{[47]}$. K. pneumoniae: Third-generation cephalosporins, carbapenems, aminoglycosides, and quinolones $L$. pneumophila: the treatment should have high intracellular concentrations like macrolide, quinolones, ketolides, tetracyclines, and rifampin ${ }^{[48]}$.

Cytokine storm- COVID-19 patients had prominent proinflammatory cytokines and chemokines, indicating a cytokine storm. Serum ferritin blood test identifies a cytokine storm. The FDA approved the interleukin- 6 receptor antagonist and its effectiveness on COVID-19 [53] Tocilizumab increase serum IL-6 levels across the bloodbrain barrier Lenzilumab increase GM-CSF secreting T cells in hospitalized patients with COVID-19 ${ }^{[49-51]}$.

Why is the problem significant in research?- With the outbreak of COVID-19, the world is facing provocation in our lifetime. Apart from adverse health, COVID-19 affected people's social, psychological, and economic loss ${ }^{[52]}$.
Research program for the next generation world- Chest CT scans can provide lung consolidation in COVID-19positive patients. It helps to enable them to provide care management. Chest CT scans can pinpoint which patients could die in the hospital from the virus ${ }^{[53]}$. The use of radiation therapy evaluates the impact of the amount of lung involvement. The scan and the therapy help in assessing the risk of in-hospital mortality and percentage of lung involvement by consolidations ${ }^{[54]}$.

Present key findings concerning central research questions- The mechanisms of fatal co-infections are complex. Impaired mucociliary clearance, and host immune responses caused by the virus, promotes bacterial growth. Primary pneumonia caused by $S$. pneumoniae is the mostcommon type of primary pneumonia ${ }^{[55]}$. Other bacteria which may cause primary pneumonia include $S$. pyogenes, $S$. pyogenes, $K$. pneumonia, $H$. influenzae, L. pneumophila and small bacteria such as $M$. pneumonia, $C$. burnetii, C. psittaci. Anaerobic organisms include $A$. israeli, are rare causes of primary pneumonia ${ }^{[56]}$. In secondary pneumonia, $H$. influenzae and some types of S. pneumoniae and certain of the bacteria forming the flora of the upper respiratory tract and mouth are the organisms most frequently cultured from sputum ${ }^{[57]}$. 
Research on the development of Lower respiratory tract microbes- The use of antibiotics has increased presently underway SARS-Cov-2 pandemic, increases the risk for resistance to antibiotics ${ }^{[58]}$.

\section{Perspectives on potential future new research work- It} is time to generate viable, reliable, cheap, more accessible testing for SARS-CoV-2. A brisk way of developing to identify antibodies that neutralize the virus. More than 100 different vaccines for SARS-CoV-2 are at various stages of development has initiated. The substantial challenge is to determine which vaccine is perfect. There is an immediate need to evaluate evidence in deciding how to treat patients [59]. A combination of drugs that work well should be analysed. Vicky et al. ${ }^{[60]}$ has generated hope. It may prove to be a magic bullet. Patients with diseases like cancer, diabetes, renal failure, CAD and pregnant women need special awareness.

Delays have dangerous ends- We are living under the microbial world. Pollution is one foot in the grave. It is green around the gills. The pathogens through polluted air cause respiratory diseases and kill at least nine million people and costs trillions of dollars every year ${ }^{[61]}$. There is continuous emergence of new and complex infectious pathogens and hence and hence early diagnosis provides ease in disease management recently use of nanotechnology, enzyme-based diagnostics became popular and shown satisfactory results.

\section{CONCLUSIONS}

In December 2019 in Wuhan, China the outbreak of nSARS-CoV2 had resulted in a global pandemic and still underway. The virus primarily infects respiratory epithelial cells via ACE2 receptor and internalized them. It has been demonstrated through several findings high viral titer trigger a massive immune response as "cytokine storm" is responsible for the collapse of the respiratory system. There has been an emphasis since the beginning that other respiratory pathogen/s may participate in co-infection. Pneumonia caused by a virus and or a bacteria ( $P$. pneumonia) affect respiratory physiology via immune invasion. The nSARS-CoV2 as a virus and $P$. pneumonia as bacteria both are respiratory pathogens and hence a higher percentage in coinfection. It has been previously reported that Flu and influenza pose an additive effect during co-infection as infected cells/tissue remain associated with impaired immunity.

In the case of nSARS-CoV2 a massive immune response due to the release of inflammatory mediators weakens host immunity and hence $P$. pneumonia finds an appropriate habitat to colonize and grow.

\section{CONTRIBUTION OF AUTHORS}

Research concept- Raghavendra Rao.M. V

Research design- Raghavendra Rao.M. V

Supervision- Raghavendra Rao.M. V

Data collection- Mubasheer Alii, Yogendra Kumar Verma, Raghavendra Rao.M. V

Data analysis and Interpretation- Raghavendra Rao.M. V, Dilip Mathai

Literature search- Mahendra Kumar Verma

Writing article- Raghavendra Rao.M. V

Critical review- Tiara Calvo Leon, Gil C Apacible, Chennamchetty Vijay Kumar

Article editing- Tiara Calvo Leon, Gil C Apacible, Chennamchetty Vijay Kumar

Final approval- Raghavendra Rao.M. V, Aruna Kummari

\section{REFERENCES}

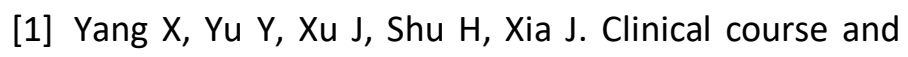
outcomes of critically ill patients with SARS-CoV-2 pneumonia in Wuhan, China: A single-centered, retrospective, observational study. Lancet Respir Med., 2020; 8(5): 475-81.

[2] Lakshmi S. Why COVID-19 patients have more pathogenic bacteria in their noses, 2021, News Medical life sciences. Available from: https://www.news-

medical.net/news/20210524/Why-COVID-19-

patients-have-more-pathogenic-bacteria-in-theirnoses.aspx.

[3] Rasoul M, Pedram G, Muhammad A, Ayda S, Hussain Ali, et al. Bacterial co-infections with SARS-CoV-2, IUBMB Life, 2020; 72(10): 2097-111.

[4] Ehsan S, Saeed S, Mohammad E, Javad K, Reza FA, et al. Evaluation of bacterial co-infections of the respiratory tract in COVID-19 patients admitted to ICU, BMC Infect Dis., 2020, 1; 20(1): 646.

[5] Nicholas SR, Amanda P, Alisha NM, Allen J, Brianna $M D$, et al. Acute SARS-CoV-2 infection is associated with an expansion of 2 bacteria pathogens in the nose including Pseudomonas Aeruginosa, Bio RXIV, 2021. 
[6] Langford BJ, So M, Raybardhan S, et al. Bacterial coinfection and secondary infection in patients with COVID-19: a living rapid review and metaanalysis. Clin Microbiol Infect., 2020; 26: 1622-29.

[7] Barth RF, Buja LM, Parwani AV. The spectrum of pathological findings in coronavirus disease (COVID19) and the pathogenesis of SARS-CoV-2. Diagn Pathol., 2020; 15: 85.

[8] Opoka-Winiarska V, Grywalska E, Roliński J. Could hemophagocytic lymphohistiocytosis be the core issue of severe COVID-19 cases? BMC Med., 2020; 18: 214.

[9] Turner GD, Bunthi C, Wonodi CB, et al. The role of postmortem studies in pneumonia etiology research. Clin Infect Dis., 2012; 54(S2): S165-71.

[10]Klein EY, Monteforte B, Gupta A, Jiang W, May L, et al. The frequency of influenza and bacterial coinfection: a systematic review and metaanalysis. Influenza Other. Respir Viruses, 2016; 10: 394-403.

[11]Shah NS, Greenberg JA, McNulty MC, Gregg KS, Riddell J, et al. Bacterial and viral co-infections complicating severe influenza: incidence and impact among 507 US patients, 2013-14. J Clin Virol., 2016; 80: 12-19.

[12]Feigin R (2004). Textbook of Pediatric Infectious Diseases ( $5^{\text {th }}$ ed.). Philadelphia: W. B. Saunders. pp. 299

[13]Stevenson A (2010). Oxford Dictionary of English. OUP Oxford. p. 1369. ISBN 978-0-19-957112-13.

[14]Tomashefski Jr JF, ed. (2008). Dail and Hammar's pulmonary pathology $\left(3^{\text {rd }}\right.$ ed.). New York: Springer. p. 228. ISBN 978-0-387-98395-0.

[15]Kobaisi Al, Jawetz MF, Melnick and Adelberg's Medical Microbiology. 24 $4^{\text {th }}$ Edition. Sultan Qaboos Univ Med J. 2007; 7(3): 273-75.

[16]Boyles TH, Brink A, Calligaro GL, Cohen C, Dheda K, et al. South African guideline for the management of community-acquired pneumonia in adults. J Thorac Dis., 2017; 9: 1469-502

[17]Woodhead M, Blasi F, Ewig S, Garau J, Huchon G, et al. Guidelines for the management of adult lower respiratory tract Infections-Summary. Clin Microbiol Infect 2011; 17(S6): 1-24.

[18]Pakhale S, Mulpuru S, Verheij TJ, Kochen MM, Rohde $\mathrm{GG}$, et al. Antibiotics for community-acquired pneumonia in adult outpatients. Cochrane Database Syst Rev 2014; 59: CD002109.

[19]Anevlavis S, Bouros D. Community acquired bacterial pneumonia. Expert Opinion on Pharmacotherapy, 2010; 11(3): 361-74.

[20]Eddy O. Community-Acquired Pneumonia: From Common Pathogens To Emerging Resistance. Emergency Medicine Practice, 2000; 7: 12.

[21]Nair GB, Niederman MS. Community-acquired pneumonia: an unfinished battle. The Medical Clinics of North America. 2011; 95(6): 1143-61.

[22] Lars F. Westblade MS, Simon Michael JS, Bacterial Coinfections in Coronavirus Disease 2019, Trends in Microbiology, 2021.

[23]Charles $F$, Ronald $A$. The role of co-infections and secondary infections in patients with COVID-19, BMC, Pneumonia, 2021; 13: 5.

[24] Harada S, Aoki K, Yamamoto S, Ishii Y, Sekiya N, et al. Clinical and molecular characteristics of Klebsiella pneumoniae isolates causing bloodstream infections in Japan: occurrence of hyper virulent infections in health care. J Clin Microbiol., 2019; 57: e01206-19.

[25]S. Hughes OT, Donaldson H, Mughal N, Moore LSP. Bacterial and fungal coinfection among hospitalized patients with COVID-19: a retrospective cohort study in a UK secondary-care setting. Clin Microbiol Infect., 2020; 26(10): 1395-99.

[26]Guo L, Wei D, Zhang X, Wu Y, Li Q, Zhou M. Clinical features predicting mortality risk in patients with viral pneumonia: the MuLBSTA Score. Front. Microbiol., 2019; 10(3): 2752.

[27]Xiaojuan Z, Yiyue G, Tao W, Kangchen Z, Yin C, et al. Co-infection with respiratory pathogens among COVID-2019 cases, Public Health Emergency COVID19 Initiative. Virus Res., 2020; 285: 198005.

[28]Zahin AC, Felicity A, Anna M, Carmen LS, David Lt, et al. Impact of the Coronavirus Disease 2019 (COVID19) Pandemic on Invasive Pneumococcal Disease and Risk of Pneumococcal Coinfection With Severe Acute Respiratory Syndrome Coronavirus 2 (SARS-CoV-2): Prospective National Cohort Study, England. Clin Infect Dis, 2021; 72(5): 1, e65-e75.

[29]Robert C. Pneumococcal Vaccination May Decrease COVID-19 Cases, Precision vaccination, 2021.

[30]GBD 2017 Influenza Collaborators. Mortality, morbidity, and hospitalisations due to influenza 
lower respiratory tract infections 2017: an analysis for the Global Burden of Disease Study 2017. Lancet Respir Med., 2019; 7: 69-89.

[31]Cawcutt K, Kalil AC. Pneumonia with bacterial and viral coinfection. Curr Opin Crit Care, 2017; 23: 38590.

[32]Chertow DS, Memoli MJ. Bacterial coinfection in influenza: a grand rounds review. JAMA, 2013; 309: 275-82.

[33]Klein EY, Milkowska-Shibata M, Tseng KK, Sharland $\mathrm{M}$, Gandra S, et al. Assessment of WHO antibiotic consumption and access targets in 76 countries 2000-15: an analysis of pharmaceutical sales data. Lancet Infect Dis., 2021; 21: 107-15.

[34]Bengoechea JA, Bamford CG. SARS-CoV-2, bacterial co-infections, and AMR: the deadly trio in COVID19? EMBO Mol. Med., 2020; 12: e12560.

[35]Canton R, Gijon D, Ruiz-Garbajosa P. Antimicrobial resistance in ICUs: an update in the light of the COVID-19 pandemic. Curr Opin Crit Care, 2020; 26: 433-41.

[36]Parameswaran GI, Sethi S. Long-term macrolide therapy in chronic obstructive pulmonary disease. CMAJ, 2014; 186(15): 1148-52.

[37]Metersky ML, Priya A, Mortensen EM, et al. Association between the Order of Macrolide and Cephalosporin Treatment and Outcomes of Pneumonia. Open Forum Infect Dis., 2017; 4(3): ofx141.

[38]Peyrani P, Wiemken TL, Metersky ML, et al. The order of administration of macrolides and betalactams may impact the outcomes of hospitalized patients with community-acquired pneumonia: results from the community acquired pneumonia organization. Infect Dis., 2018; 50(1): 13-20.

[39]Grossman RF, Hsueh PR, Gillespie SH, et al. Community-acquired pneumonia and tuberculosis: differential diagnosis and the use of fluoroquinolones. Int J Infect Dis., 2014; 18: 14-21.

[40]Low DE. Fluoroquinolones for treatment of community-acquired pneumonia and tuberculosis: putting the risk of resistance into perspective. Clin Infect Dis., 2009; 48(10): 1361-63.

[41]Management of community-acquired pneumonia. J Assoc Physicians India, 2013; 61(7 Suppl): 20-23.

[42]Sibila O, Rodrigo-Troyano A, Torres A. Nonantibiotic Adjunctive Therapies for Community-Acquired
Pneumonia (Corticosteroids and Beyond): Where Are We with Them? Semin Respir Crit Care Med., 2016; 37(6): 913-22.

[43]Feldman C, Anderson R. Corticosteroids in the adjunctive therapy of community-acquired pneumonia: an appraisal of recent meta-analyses of clinical trials. J Thorac Dis. 2016; 8(3): E162-71.

[44]Boyles TH, Brink A, Calligaro GL, et al. South African guideline for the management of communityacquired pneumonia in adults. J Thorac Dis., 2017; 9(6): 1469-502.

[45]FDA Drug Safety Communication. FDA updates warnings for oral and injectable fluoroquinolone antibiotics due to disabling side effects (last accessed 27 February 2018).

[46]Miravitlles $M$, Soler-Cataluña JJ, Calle $M$, et al. Spanish Guidelines for Management of Chronic Obstructive Pulmonary Disease (GesEPOC) 2017. Pharmacological Treatment of Stable Phase. Arch Bronconeumol., 2017; 53(6): 324-35.

[47]Spagnolo P, Fabbri LM, Bush A. Long-term macrolide treatment for chronic respiratory disease. Eur Respir J., 2013; 42(1): 239-51.

[48]Simoens S, Laekeman G, Decramer M. Preventing COPD exacerbations with macrolides: a review and budget impact analysis. Respir Med., 2013; 107(5): 637-48.

[49]Singleton R, Hammitt L, Hennessy T, et al. The Alaska Haemophilus influenzae type $b$ experience: lessons in controlling a vaccine-preventable disease. Pediatrics. 2006. 118(2): e421-29.

[50]Williams DJ, Cooper WO, Kaltenbach LA, Dudley JA, Kirschke DL, et al. Comparative Effectiveness of Antibiotic Treatment Strategies for Pediatric Skin and Soft-Tissue Infections. Pediatrics, 2011; 128(3): e47987.

[51]Shahab Qureshi, Klebsiella Infections Treatment \& Management [Internet]. Available from: https://emedicine.medscape.com/article/219907treatment [Updated: Jun 10, 2019].

[52]Stout JE, Sens K, Mietzner S, et al. Comparative activity of quinolones, macrolides and ketolides against Legionella species using in vitro broth dilution and intracellular susceptibility testing. Int J Antimicrob Agents, 2005; 25(4): 302-07. 
[53]Li X, Geng M, Peng Y, Meng L, Lu S. Molecular immune pathogenesis and diagnosis of COVID-19. J Pharm Anal., 2020; 10(2): 102-08.

[54]Zhao Z, Wei Y, Tao C. An enlightening role for cytokine storms in coronavirus infection. Clin Immunol., 2021; 222: 108615.

[55]Mehta P, McAuley DF, Brown M, Sanchez E, Tattersall RS, et al. COVID-19: consider cytokine storm syndromes and immune suppression. Lancet, 2020; 395(10229): 1033-34.

[56]Slater H (26 March 2020). FDA Approves Phase III Clinical Trial of Tocilizumab for COVID-19 Pneumonia. cancernetwork.com. Cancer Network, Retrieved 22 April 2020.

[57]Locke FL, Neelapu SS, Bartlett NL, Lekakis U, Jacobson CA, et al. Preliminary Results of Prophylactic Tocilizumab after Axicabtagene ciloleucel (axi-cel; KTE-C19) Treatment for Patients with Refractory, Aggressive Non-Hodgkin Lymphoma (NHL). Blood, 2017; 130(S1): 1547.
[58]Sterner RM, Sakemura R, Cox MJ, Yang N, Khadka $\mathrm{RH}$, et al. GM-CSF inhibition reduces cytokine release syndrome and neuro-inflammation but enhances CAR $T$ cell function in xenografts. Blood, 2019; 133(7): 697-709.

[59]Pettersson H, Manley B, Hernandez S. Tracking Coronavirus' Global Spread. https://www.cnn.com/ interactive/2020/health/coronavirus-maps-andcases [accessed May 29, 2020].

[60]Whitney JP. COVID-19 Lung Involvement Captured on CT Can Help Predict Mortality Risk, Diagnostic imaging, 2021.

[61]Vicky Sr, Karina H, Birgitta HN. Virus-Induced Changes of the Respiratory Tract Environment Promote Secondary Infections with Streptococcus pneumonia. Front Cell Infect Microbiol., 22; 11: 643326.

\section{Open Access Policy:}

Authors/Contributors are responsible for originality, contents, correct references, and ethical issues. SSR-IIJLS publishes all articles under Creative Commons Attribution- Non-Commercial 4.0 International License (CC BY-NC). https://creativecommons.org/licenses/by-nc/4.0/legalcode (c) (i) (8) 